\title{
SOURCE AND AGE OF GROUND-WATER SEEPAGE TO STREAMS
}

\section{Introduction}

Contaminants from point and nonpoint sources can degrade aquatic ecosystems and render many streams unsuitable for drinking and recreational use. Contaminants can be transported to streams by ground water and by runoff from rainfall. In many unconfined aquifer systems, ground-water seepage (base flow) is the principal source of water to streams, because streams are fed continuously by ground water but only episodically by runoff.

Because ground water that seeps to a stream can originate from both nearby and distant sources, its age can vary widely. Therefore, the base-flow component of streamflow is an integration of waters of different chemical compositions that reflect the effects of land-use practices in different locations and at different times. Effective water-quality management requires

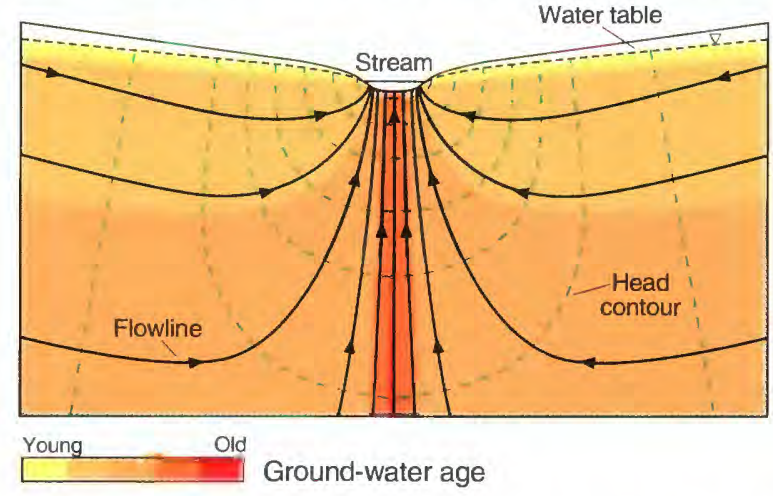

Figure 1. Conceptual model of flow patterns and age of ground-water seepage to a stream channel.

an understanding of the relations among ground-water age, sources of recharge, and ground-water seepage to streams. To investigate these relations, Modica and others (1998) developed a numerical model to simulate flow in an unconfined streamaquifer system in the Atlantic Coastal Plain of New Jersey. This Fact Sheet describes source areas, flow paths, and the ages of ground-water seepage to streams; summarizes the results of the simulation analysis; and explores the potential application of the results of the analysis to water-resource management.

\section{Age of Ground-Water Seepage to Streams}

A conceptual model of ground-water flow beneath a stream channel (fig. 1) indicates that water recharges the aquifer from a relatively wide source area and converges as discharge to the stream channel. In this model, ground water that seeps into the stream near its banks originates near the stream, follows short flow paths, and requires short travel times. Ground water that seeps into the center of the stream channel originates from distant areas, follows relatively long flow paths, and requires longer travel times to move through the aquifer. As a result, the age of

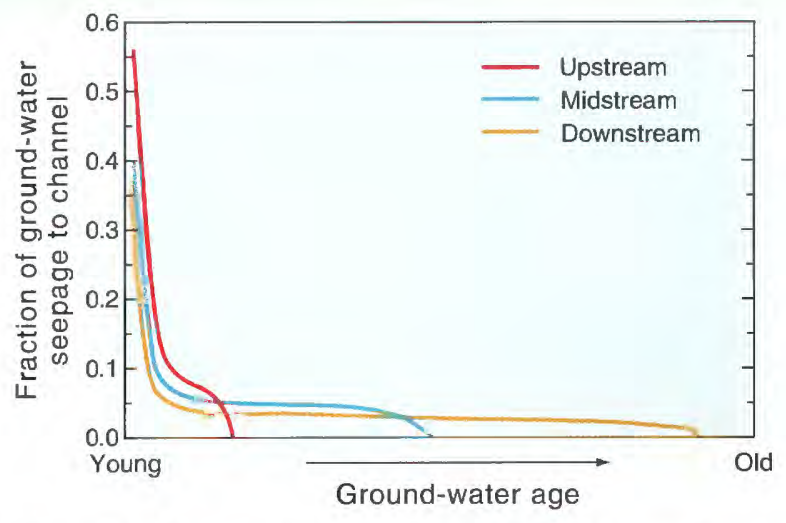

Figure 2. Generalized age distribution of ground-water seepage to upstream, midstream, and downstream reaches.

ground-water seepage across a section of the stream channel increases from its banks to its center. Ground-water seepage also becomes increasingly older with distance downstream (Modica and others, 1997). Consequently, the range of the age of groundwater seepage across stream channels is greater in downstream reaches than near the headwaters (fig. 2).

\section{Relation Between Nonpoint-Source Contaminants and Ground-Water Age}

Nonpoint-source contaminants originating from a particular land-use activity enter ground-water systems over broad areas. As a result, large volumes of ground water can be affected by contamination. The extent of contaminated ground water is defined by the extent and distribution of flow paths from the source area and by the ages of ground water that was recharged during the period of the activity that contributed the contaminant.

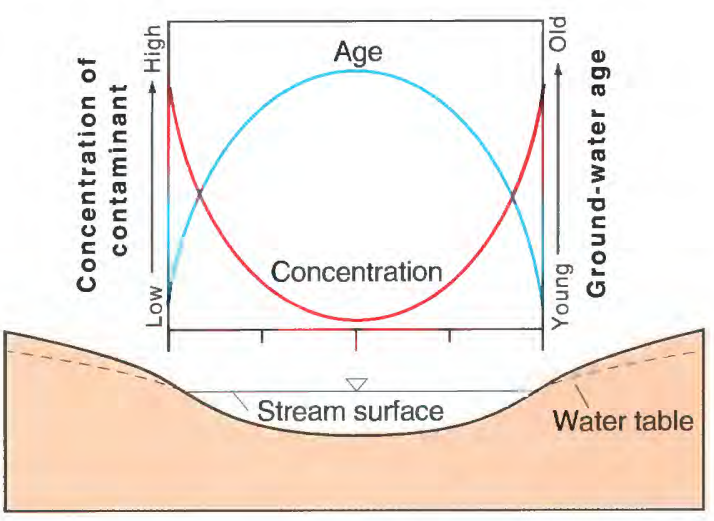

Figure 3. Generalized relation between contaminant concentration and age of groundwater seepage to a stream channel. 


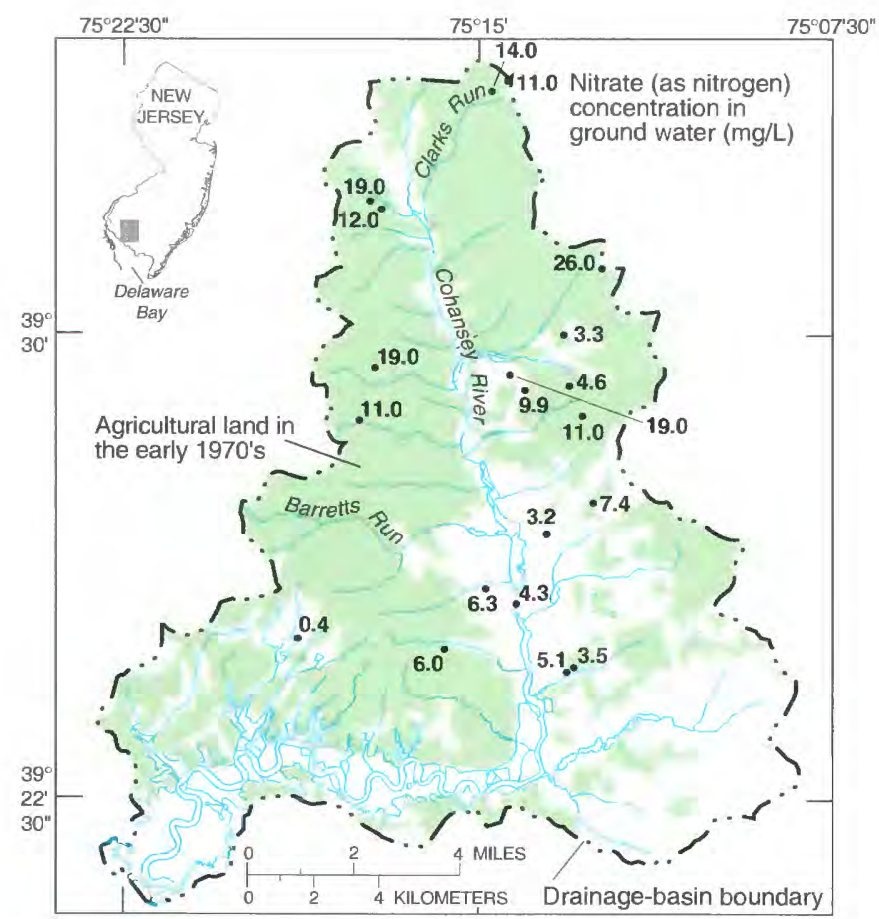

Figure 4. Distribution of agricultural land and nitrate in ground water in the Cohansey River Basin, New Jersey.

The relation between the concentration of a nonpointsource contaminant associated with a recent and persistent land use and the age of ground-water seepage along a stream channel is represented in figure 3 . Concentrations of the contaminant are highest in the youngest ground water, which flows through the shallow part of the aquifer system and discharges near stream banks. Progressively lower concentrations of the contaminant are associated with older ground water, which flows through deeper parts of the aquifer and discharges near the center of the channel.

\section{Source and Age of Ground-Water Seepage to the Cohansey River}

The Cohansey River Basin in southern New Jersey occupies approximately $264 \mathrm{~km}^{2}$ and is underlain by an extensive unconfined aquifer. Ground water recharged from precipitation discharges predominantly to the Cohansey River. Agriculture comprises nearly 60 percent of land use in the basin (fig. 4), where nitrogen from synthetic fertilizers has entered the groundwater system relatively uniformly and in progressively higher concentrations since the early part of the century. Concentrations of nitrate (as nitrogen) in water samples from wells screened in the unconfined aquifer in this area can exceed the $10-\mathrm{mg} / \mathrm{L}$ drinking-water standard set by the U. S. Environmental Protection Agency.

\section{Simulation of ground-water flow}

A ground-water flow model was developed for the unconfined aquifer system that underlies the Cohansey River Basin (fig. 5). The simulated average water-table configuration indicates that ground water discharges to the Cohansey River. Particle tracking was used to delineate the source areas of flow to several stream reaches. The source area of flow to Clarks Run, a headwaters tributary (fig. 5), is almost evenly apportioned on either side of the stream. In contrast, the source area of flow to
Barretts Run is on the "upbasin" side of the stream. The difference in source-area configuration is caused largely by the fact that Clarks Run generally flows parallel to the direction of ground-water flow, whereas Barretts Run, which enters the Cohansey River nearly perpendicularly from the west, flows at an angle to the direction of ground-water flow. The source area to the upper reach of the Cohansey River and its tributaries extends to the upper basin boundary. The location and extent of this source area indicate that land use both near the stream and as far away as the drainage divide affects the quality of water in these reaches.

The source area of flow to reach T2 of the Cohansey River (fig. 6) extends to the divide on either side of the basin. The lines of equal residence time (the time ground water remains in the aquifer) that cross the source area of flow to reach $\mathrm{T} 2$ indicate that most ground water that flows to $\mathrm{T} 2$ is relatively young (less than 20 years old). Forty-seven percent of the ground water that

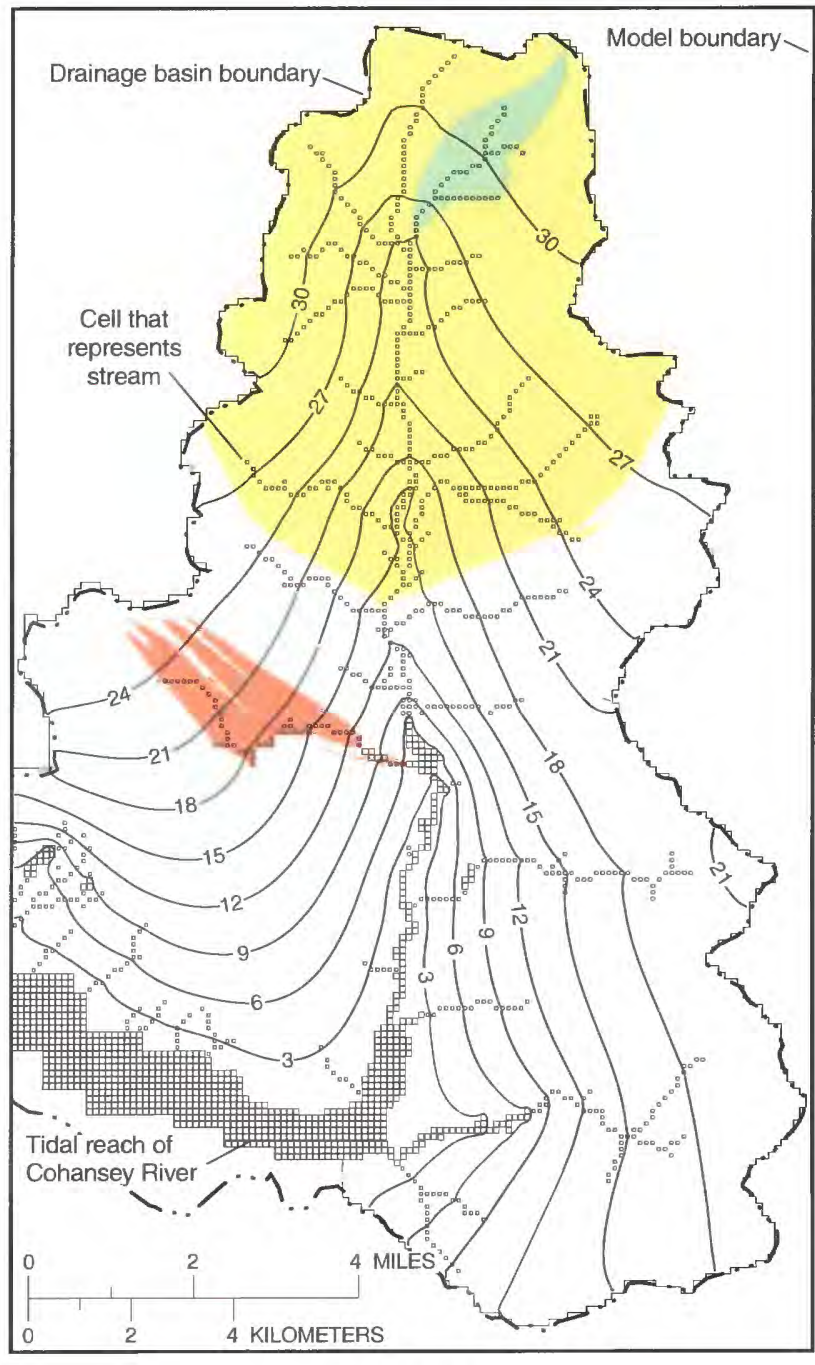

EXPLANATION

Source area of flow to upper Cohansey River and tributaries

Source area of flow to Barretts Run and tributaries

Source area of flow to Clarks Run and tributaries

- 15- Simulated water-table contour (interval 3 meters)

Figure 5. Simulated water table and source areas of flow to the upper Cohansey River and to Barretts Run. 


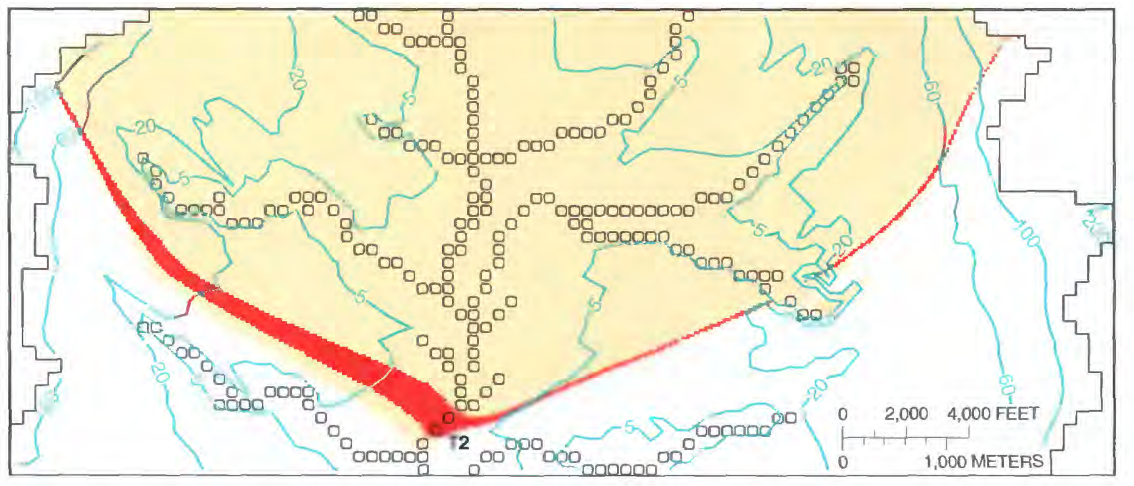

\section{EXPLANATION}

Source area of flow to upper Cohansey River and tributaries

Source area of flow to T2 at Cohansey River

Line of equal ground-water residence time, in years

Cell that represents upper Cohansey River and tributaries

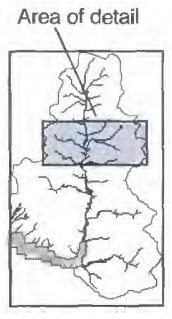

Figure 6. Simulated ground-water residence time and source area of flow to the upper reaches of the Cohansey River and its tributaries.

flows to T2 takes less than 10 years, and more than 72 percent takes less than 20 years to move through the aquifer: less than 1 percent of the ground water that flows to $\mathrm{T} 2$ remains in the aquifer longer than 100 years. Water with the longest residence time enters the aquifer near the extreme edges of the source area, farthest from the river.

Simulation results show that the age of ground water seeping into a stream ranges from young near the edge of a simulated stream to old near its center, as demonstrated in the conceptual model (figs. 1 and 3). Furthermore, the average age becomes progressively greater with distance downstream (fig. 2). Unlike the idealized symmetrical distributions of ground-water age entering a stream channel shown in figure 3 , however, the age distribution across a real stream can be "shifted." In the case of Barretts Run, for example, the oldest ground water enters the stream channel closer to the northern bank.

\section{Chemical analysis of ground-water samples}

Ground-water samples collected directly beneath the streambed along stream transects in the Cohansey River Basin were analyzed for nitrogen and for chlorofluorocarbons (CFC's), to identify water affected by agricultural land use and to estimate the age of ground water discharging to the stream. CFC concentrations can be used to determine the age of ground water less than about 50 years old (Plummer and others, 1993).

The Cohansey River at T2 (fig. 6) is a broad flood channel that is approximately 200 meters wide. Nitrate (as nitrogen) concentrations at 20 sampling points along a transect at the middle of $\mathrm{T} 2$ are shown in figure 7. In general, the pattern of nitrate concentrations across the stream is similar to that predicted by the conceptual and computer models-

concentrations are high near the banks and low near the center of the channel. Concentrations were 13 and $9.7 \mathrm{mg} / \mathrm{L}$ near the western and eastern edges of the transect, respectively, and decreased to $0.76 \mathrm{mg} / \mathrm{L}$ near the center. The low nitrate concentration found at the eastern end of the transect $(0.05 \mathrm{mg} / \mathrm{L})$ is attributed to uncontaminated recharge that enters the system through woodlands near the edge of the channel.

Ground-water ages indicated by CFC concentrations increased from about 2 years near the edges of the transect to about 30 years near the center of the channel. These data are generally consistent with simulation results that indicate that ground water entering the stream at $\mathrm{T} 2$ is relatively young, with some older water near the center of the channel.
Patterns of nitrogen concentration and age distribution along other stream transects were similar, with the lowest nitrogen concentrations near the centers of stream channels and the highest concentrations near the edges of stream channels. Also, concentrations of nitrogen in ground water along transects near stream headwaters were higher and varied less than those along downstream transects.

\section{Potential Applications to Water-Resource Management}

The results of this study can be applied to other unconfined aquifer systems with gaining streams to illustrate how groundwater seepage can affect the quality of surface water. The effects of human activities on ground-water quality manifest themselves on surface-water quality first in upstream reaches. Furthermore, surface-water quality in upstream areas can provide an indication of future conditions at downstream sites whose drainage areas are larger.

The results of this study can be used to help design monitoring networks intended to determine the effects of nonpoint-source contaminants that travel in ground water and affect surface-water quality. Analysis of the relatively young ground water that provides base flow in upstream reaches provides the best estimate of the effects of recent and local land use. Although samples from wells near stream channels can integrate water from various sources and of various ages, wells near banks yield young, local water. The orientation of stream

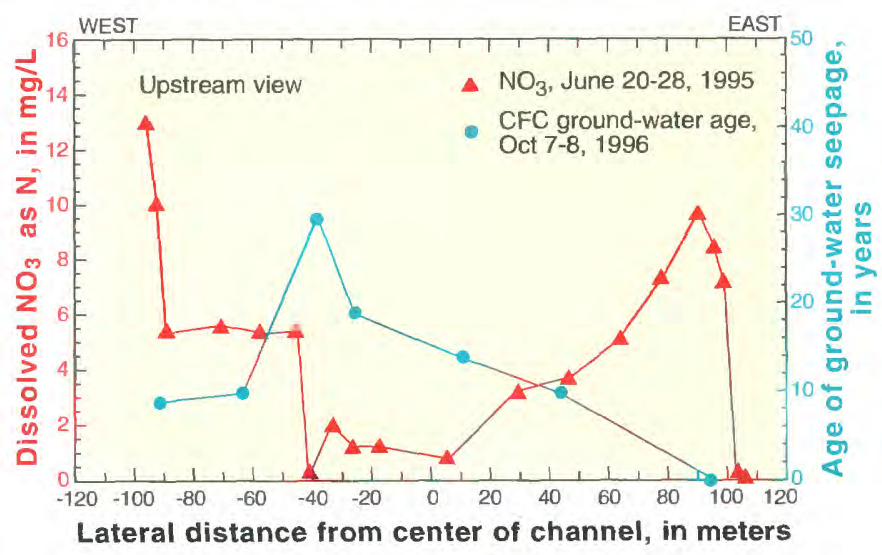

Figure 7. Relation between ground-water age and dissolved nitrate in ground-water seepage to a transect on the Cohansey River. 
channels with respect to the general direction of ground-water flow can be used to estimate the location of the source area and assist in the design of streamwater-sampling protocols used to evaluate the effects of local land use on streamwater quality.

The results of this study also could be used in the formulation of regulatory policies that govern water-supply allocation, instream-flow requirements, and chemical-discharge allocation decisions needed to balance the development of ground-water supply with the protection of wetlands and streams. The formulation of such policies requires an understanding of the complex hydrologic and chemical interrelations of ground and surface water. The findings of this study show that elevated concentrations of nitrate in streams can be sustained by continuous ground-water seepage. Excess nitrate and other nutrients can accelerate eutrophication of estuaries and lakes by reducing dissolved-oxygen concentrations and altering habitats and food sources, and also can affect the ability of streamwater to support fish propagation or maintenance.

The method used in this study - a numerical flow model coupled with water-quality-data collection - can be an effective tool for helping to assess the effects of land-use practices on the quality of surface and ground water. The method can be used to establish links between the source of contamination and the affected stream reach by using the model to identify stream source areas and by sampling discharging ground water beneath the streambed to determine the level of contamination. The delineation of source areas with a model is especially useful where the source areas are highly irregular or asymmetrically distributed around the stream, as in the case of Barretts Run.

The model can be used to determine the effects of land-use policies on streamwater quality. The model of the Cohansey River Basin is used as an example. If the contaminants in ground water are assumed to move advectively through the aquifer, and if intense, widespread nitrogen application throughout the basin begins in the present and continues unabated, the fraction of streamwater in the upper Cohansey River Basin (upstream from reach $\mathrm{T} 2$ in figure 6 ) that becomes contaminated would increase asymptotically with time and would equal 51 percent in 10 years, 76 percent in 25 years, and 89 percent in 45 years. The remaining streamwater would be derived from ground water that predates nitrogen application and presumably would be uncontaminated (fig. 8).

Consider the long-term effect on the quality of streamwater of eliminating the source of nitrogen contamination and allowing clean (uncontaminated) ground water to replace contaminated water. The simulation results show that the percentage of contaminated streamwater would decrease exponentially (fig. 8); if the source of nitrogen contamination were eliminated 45 years from the present, then within 10 years afterward, the percentage of contaminated water reaching the stream would decrease to about one-half the value at the time the source was eliminated (from 89 to 46 percent), and would decrease to about 24 percent after 20 years from that time. This is because a large proportion of ground water that discharges to streams is young and takes relatively little time to travel along short flow paths.

Contaminated ground water that travels along deeper and longer flow paths, however, would require more time to be replaced by uncontaminated water. Consequently, the rate of decrease in contamination of streamwater would decrease with time, and

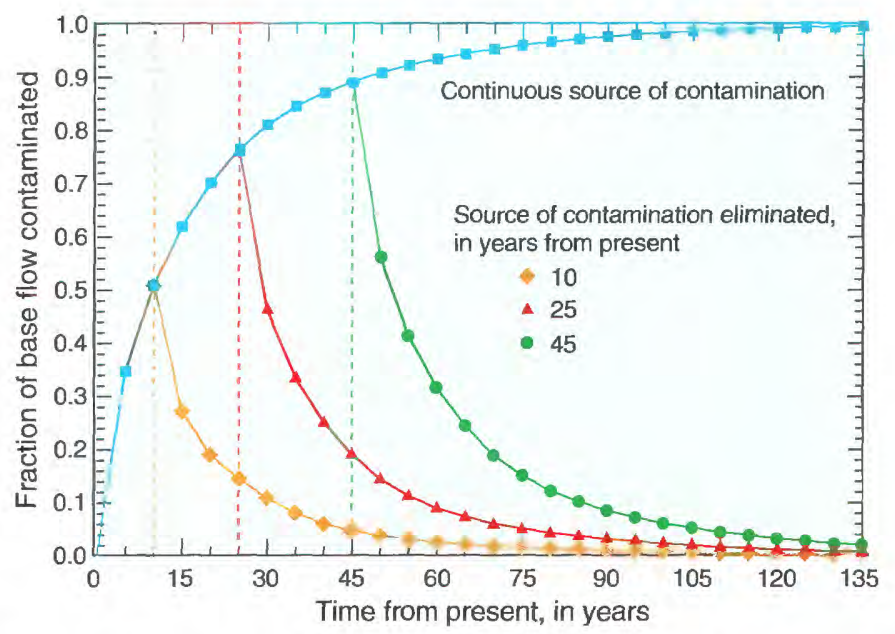

Figure 8. Simulated changes in the contamination of streamwater with time in streams in the Cohansey River Basin.

some contaminants would be found in streamwater even 100 years after elimination of the source.

Similarly, if the source of nitrogen contamination were eliminated 25 or 10 years from the present, the proportion of contaminated streamwater would decrease exponentially, but streamwater would become cleaner earlier than water whose source of contamination were eliminated at later times because there would be less older, contaminated ground water in the aquifer to be replaced.

Although the results of this study can be generalized to other unconfined stream-aquifer systems, variations in system properties, such as aquifer thickness, aquifer transmissivity, and drainage density, would cause different responses.

-Edward Modica

\section{References Cited}

Modica, E., Buxton, H. T., and Plummer, L.N., 1998, Evaluating the source area and residence times of ground-water seepage to streams, New Jersey Coastal Plain: Water Resources Research, v. 34, no. 11, p. 2797-2810.

Modica, E., Reilly, T. E., and Pollock, D.W., 1997, Patterns and age distribution of ground-water flow to streams: Ground Water, v. 35 , no. 3 , p. 523-537.

Plummer, L. N., Michel, E. M., Thurman, E. M., and Glynn, P. D., 1993, Environmental tracers for age-dating young ground water, in Alley, William, ed., Regional ground-water quality: New York, Van Nostrand Reinhold, p. 255-294.

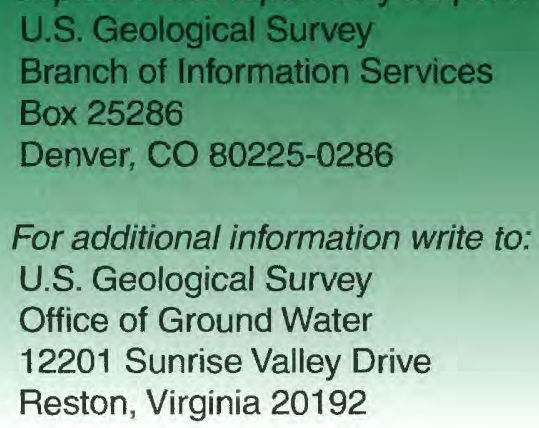

